pressure. There has never been in her case any sign of cortical irritation either of the sensory or motor cortex. A few cases have been reported in which there are thickenings of the soft tissues accompanying the bony changes in leontiasis ossea. This patient shows no change in the soft tissues at all.

\title{
CASE I. TABES DORSALIS (AMAUROTIC TYPE)
}

\section{By D'Orsay Hecht, M.D.}

Dr. Heclit said the patient was a member of the City Fire Department in active service on the hook and ladder. He was 37 years of age; married at the early age of 20 , and was the father of several very healthy children. He had exposed himself to venereal disease in his youth and acknowledged to lapses of fidelity even during his married life, but failed to recall a single instance of gonorrhea, or any other venereal sore. It may be said that there is some somatic evidence of past lues in a general adenopathy and bony thicknesses of the tibia. Confining oneself to the conspicuous tabetic symptoms: The pupils are widely dilated and of the Argyll Robertson type; the fundus of the right eye is chalky white, that of the left disc gray white. The optic atrophy is complete. Vision is very seriously impaired. The patient can distinguish fingers held closely before his eyes; he can at best in a gray light appreciate a moving figure, that is all. The knee jerks and Achilles jerks are absent, the cremaster is present, the sexual power is good. Trunk anesthesia is manifest in a border about eight inches in width encircling the thorax. He presents little or no ataxia of gait; has no Romberg and reveals imbalance only when he stands on the right foot alone. Slight bladder involvement in the form of incontinence. The onset and advance of the tabes has been so insidious and attended with so little discomfort except for a few lumbo-sacral lancinating pains that only within the past few months when his vision began to fail appreciably, has he realized the presence of the disease. It is important to note that even though his vision was very defective in February, Igo8, he nevertheless attended fires, setting up ladders against high downtown buildings, and doing all that was part of his work with the hook and ladder company, and doing it as well as he ever did. In February, however, he began to realize the dangers that could arise from his poor eye-sight and asked to be put on lighter duty. $\mathrm{He}$ is at the present time doing fire-watch service for the Ringling Bros. circus at the Colliseum. He was referred to Dr. Pardee and only by close inspection and observation could it be noticed that he had any impairment of his vision. Of ataxia there was none. It was Dr. Hecht's comment of the case that in the amaurotic type of tabes incoördination symptoms are known to remain in abeyance. This is the common experience and has been satisfactorily explained. The case is unique, however, because of the fact that despite the presence of all the classic symptoms of frank and advanced tabes including the highest degree of optic atrophy the patient has been able to follow his occupation and is even now not embarrassed by the service required of him. 


\section{CASE II. INFANTILE CEREBRAL PARALYSIS DUE TO POLIOENCEPHALITIS}

The second case presented by Dr. Hecht was one of infantile cerebral monoplegia presumably of polioencephalitic origin. Dr. Hecht said: "This boy now seven years old experienced at the age of five years an acute illness which the mother says ran a course something as follows: On a Saturday afternoon the boy was out playing and felt well. In the evening the mother noticed he was warm and concluded there was some fever. She gave the boy a cooling bath. While in the bath the boy chilled. It was impossible to determine whether this was a genuine chill or merely a sense of chilliness. That night the boy slept very restlessly, starting up in his sleep and displaying a good deal of ncrvousness and irritability. The following morning he seemed well enough to go to Sunday-school. On his return from Sunday-school the mother for the first time noticed a slight limping and dragging of the right limb. This persisted for three or four days and then occurred a rise in temperature. A physician was called and noticed that the right leg was swollen as far as the knee, edematous and glossy. On the left leg there appeared large red, circumscribed patches of quarter-dollar size. The physician called a consultant and it was their joint opinion that the condition was one of rheumatic purpura. The disability in the right leg seemed to improve, but of the exact time there is no certainty because the child was in bed for three weeks. However, at the end of a month the boy got up and the legs swelled a second time. He was returned to bed for another period of three weeks and the disability in the right leg again became apparent. There had been neither delirium, nor clouding of the sensorium. At the end of this second three weeks the child got up only to be returned to bed with a third recurrence. With this last attack the spots began to fade out, the febrile symptoms disappeared, and there remained only the incomplete monoplegia affecting the right leg.

Dr. Hecht saw the boy for the first time at the Northwestern University Neurologic Clinic about a week ago. The child has limped these past two years to such an extent that raising the shoe one half inch to accommodate the limp has seemed necessary. The sloping of the right shoulder is owing to posture only. The arms and shoulders are normal. There is no atrophy. The disability is so slight as to be hardly noticeable in the gait, but on physical examination the knee jerk on the affected side is distinctly increased as compared with the left as is also the Achilles, and in addition there is a typical Babinski sign. The abdominal skin reflexes are normal.

Dr. Hecht demonstrated the disparity in these contralateral reflexes. $\mathrm{He}$ mentioned that there are no sensory changes or trophic disturbances. With this history, mode of onset, and the remnant of paralytic involvement of only a single extremity the diagnosis of cerebral monoplegia of subcortical origin might be ventured with some degree of positiveness and Dr. Hecht thought the lesion could be brought into direct causal relation with the purpura rheumatica. It would hardly be tenable to suppose a pyramidal tract involvement. Dr. Hecht's conclusion was that the case rightfully belonged in the rubric of those cases described and designated as polioencephalitis. 